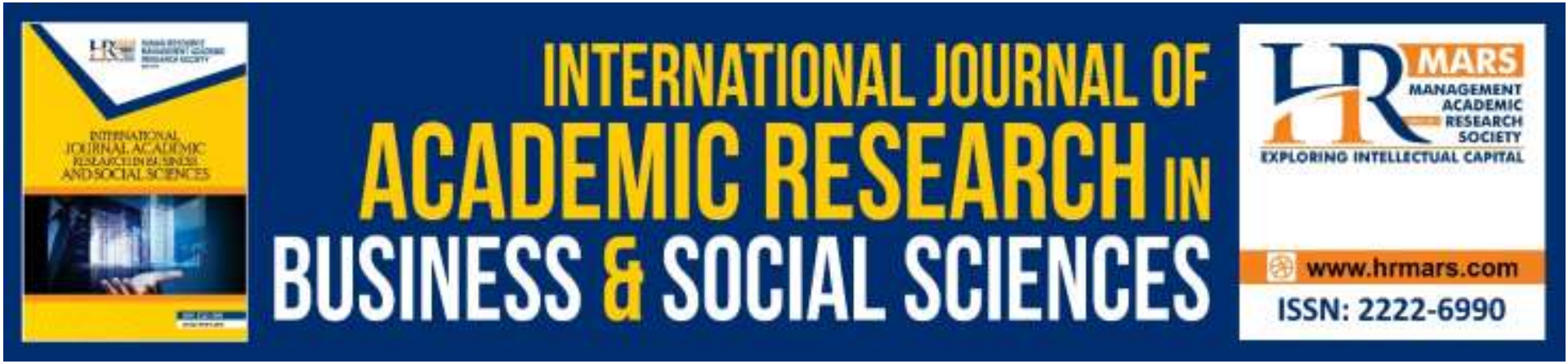

\title{
A Review on Marriage Education in Malaysian Higher Education Curriculum
}

\author{
Nizaita Omar, Zulkifly Muda, Siti Murdiah Salleh
}

To Link this Article: http://dx.doi.org/10.6007/IJARBSS/v9-i10/6483

DOI: 10.6007/IJARBSS/v9-i10/6483

Received: 10 Sept 2019, Revised: 27 Sept 2019, Accepted: 03 Oct 2019

Published Online: 28 Oct 2019

In-Text Citation: (Omar, Muda, \& Salleh, 2019)

To Cite this Article: Omar, N., Muda, Z., \& Salleh, S. M. (2019). A Review on Marriage Education in Malaysian Higher Education Curriculum. International Journal of Academic Research in Business and Social Sciences, 9(10), 218-228.

\section{Copyright: (C) 2019 The Author(s)}

Published by Human Resource Management Academic Research Society (www.hrmars.com)

This article is published under the Creative Commons Attribution (CC BY 4.0) license. Anyone may reproduce, distribute, translate and create derivative works of this article (for both commercial and non-commercial purposes), subject to full attribution to the original publication and authors. The full terms of this license may be seen

at: http://creativecommons.org/licences/by/4.0/legalcode

Vol. 9, No. 10, 2019, Pg. 218 - 228

Full Terms \& Conditions of access and use can be found at http://hrmars.com/index.php/pages/detail/publication-ethics 


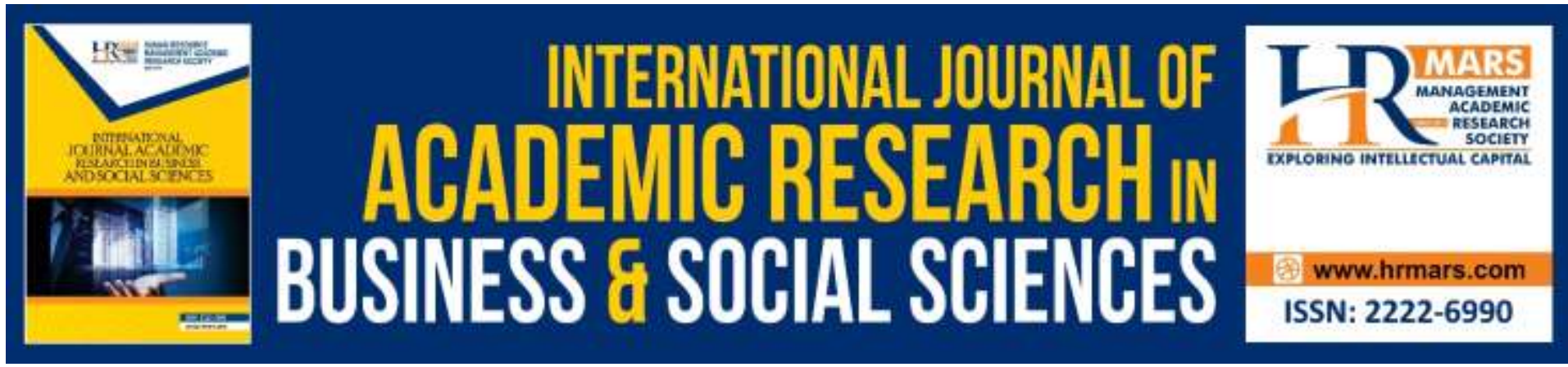

\title{
A Review on Marriage Education in Malaysian Higher Education Curriculum
}

\author{
Nizaita Omar ${ }^{1}$, Zulkifly Muda ${ }^{2}$, Siti Murdiah Salleh ${ }^{3}$ \\ ${ }^{1}$ Faculty of Islamic Contemporary Studies, Universiti Sultan Zainal Abidin (UniSZA), Gong \\ Badak Campus, 21300 Kuala Nerus, Kuala Terengganu, Terengganu, Malaysia, ${ }^{2}$ Fatwa \\ Department of Terengganu, Centre of Islamic Affair, Kuala Terengganu, Malaysia, ${ }^{3}$ Faculty \\ of Islamic Contemporary Studies, Universiti Sultan Zainal Abidin (UniSZA), Gong Badak \\ Campus, 21300 Kuala Nerus, Kuala Terengganu, Terengganu, Malaysia
}

\begin{abstract}
Marriage is one of the religious requirements in Islam that purposes to fulfill one's needs and ensure human generation's continuity. A marriage built with strong foundation is the main footing of producing a family of physical, mental, emotional and spiritual qualities. The formation and development of a family institution becomes the social agent to the success of a civilisation. In Malaysia particularly, the phenomenon of the breakdown of family institution is getting more alarming. Statistics issued by the Department of Islamic Development in Malaysia (JAKIM) on the divorce rate among Malaysians from 1995 to 2006 show constant increase from year to year. Most of the divorce cases involve couples of young adults. Also, a report done in 2007 suggested that 59.9 percent of the divorces involve marriages aged less than 10 years old. Hence, this research is done to observe and scrutinise the role of higher education system in Malaysia in providing knowledge and creating awareness on the values of marriage and family institution. 20 public universities in Malaysia are included to take part in this research. Structure of academic programs is analysed based on the progress of Mata Pelajaran Umum (General Studies Modules) or MPU as well as elective modules offered in these universities. The findings obtained will manifest the participation of these public universities in the government's mission of minimizing the divorce rates among young couples, and subsequently inhibiting the breakdown of family institution that might contribute to crimes and other negative issues in the long run.
\end{abstract}

Keywords: Marriage, Family Institution, Divorce, Malaysian Higher Education, Curriculum

\section{Introduction}

A great society comes from an organized and sustained family institution. Family institution that is well preserved becomes the core for excellent civilisation and social development (Hasliza and Hanizam, n.d.). Righteous personality from each partner in a marriage is essential to produce a harmonious, affectionate and empathetic family in forming a loving and respected society as a whole, as asserted in one of the national visions (Ghazali and Al-Hadi, 2004). 
Preparation in terms of knowledge and understanding of marital and familial issues is important to every individual who is about to be in a marriage. Mastery in leadership, management and decision-making is particularly required to be brought in a marriage. Comprehension in matters like child development, psychology, education and health would also help in fulfilling responsibilities as a husband, a wife and later a parent (Mustafa Daud, n.d.). In addition, conflict management skills along with truthful traits might as well be useful for these individuals to possess as a preparation for the challenges and conflicts that they might encounter within their marriage or among family members in the future (Ghazali and Al-Hadi, 2004).

Accordingly, considering the importance of good family institution as a major contributor to the excellence of a nation as well as the challenges that we are now facing in making it a reality, a course called the Pre-Marital Course is introduced. The course is compulsory to those who are going to tie the knot and provides the information and skills needed in a marriage. It aims to assist the couples in understanding the importance of maintaining and preserving a marriage and a family, and at the same time diminish the divorce rate in this country in general.

\section{Problem Statement}

Marital education is a form of education that is created to help couples attaining success and happiness in their marriages. It is not only restricted to Pre-Marital Course but also other related supporting programs, and it should be on recurring basis, not only before or at the beginning of a marriage (Nubailah \& Zuria, 2014).

Programs or courses that deal with marital-related issues such as Fiqh Munakahat need to be obliged to be attended by young couples before they proceed with marriage. This is due to increasing rate of divorce from year to year even though the Pre-Marital Course is made compulsory. Statistics released by the Judiciary Department of Malaysia as presented in Table 1 show the divorce rate's increment from 2010 to 2014. 236855 divorce cases were reported to occur during the period of 5 years with the increasing percentage of 22.9 percent.

Table 1: Statistics of the Divorce Rate from 2010 to 2014

\begin{tabular}{cc} 
Year & No. of Cases \\
\hline 2010 & 41,544 \\
\hline 2011 & 43,749 \\
\hline 2012 & 48,029 \\
\hline 2013 & 49,663 \\
\hline 2014 & 53,870 \\
\hline TOTAL & $\mathbf{2 3 6 8 5 5}$
\end{tabular}

Source: Adapted from the Judiciary Department of Malaysia (2016)

A study done by JAKIM in 2007 finds that 32.2 percent of marriages aged five years and below ended with divorce. For those aged six to 10 years, about 27.7 percent of them collapsed, making marriages aged 0 to 10 years made up 59.9 percent from the total divorce. This proves that the first 10 years of marriage is a very critical span (Othman, 2011). Tacitly, this research suggests an indication that most of the divorce cases involve couples of a young age. 
Statistics from the Social Welfare Department of Malaysia in 2014 propose that among the main factors children from protection centres ended there is familial issues (Table 2). Parent(s)' failure of mastering parenting skills contributes most to the cases.

Table 2: Statistics of Children from Protection Centres in 2014

NO.

REASON OF PERSECUTION

NO. OF

\begin{tabular}{|c|c|c|}
\hline 1. & Mother's departure with boyfriend & 732 \\
\hline 2. & Family dispute & 715 \\
\hline 3. & Parents/guardians' negligence & 606 \\
\hline 4. & $\begin{array}{l}\text { Brought up by people other than } \\
\text { parents/guardians }\end{array}$ & 119 \\
\hline 5. & $\begin{array}{l}\text { Abuse by those with background of traumatic } \\
\text { abuse }\end{array}$ & 20 \\
\hline 6. & Abuse by those suffered from mental illness & 113 \\
\hline 7. & Gamblers & 27 \\
\hline 8. & Superstition & 13 \\
\hline 9. & Drug addicts & 175 \\
\hline 10. & Hyperactivity & 62 \\
\hline 11. & Stepchildren & 163 \\
\hline 12. & Financial issues & 390 \\
\hline 13. & Illegitimate status of children & 232 \\
\hline 14. & Criminal involvement & 71 \\
\hline 15. & Hypersexuality & 121 \\
\hline 16. & Children with disabilities & 36 \\
\hline 17. & Alcoholics & 107 \\
\hline 18. & Unknown & 200 \\
\hline 19. & Others & 403 \\
\hline & Total & 4295 \\
\hline
\end{tabular}

Source: The Social Welfare Department of Malaysia 2014

Parents' ignorance on the nurture of children is also seen as one of the reasons for children's involvement in criminal cases. In 2014, the number of children who are involved in crimes is at its highest when they are under the care of their parents, which totals 3371 cases (Table $3)$. This indicates that these parents are lacking knowledge or skills in the ways they nurture and educate their children. These skills are crucial as their responsibility is not merely restricted to provide a roof over their children's head, but rather unrolled to every aspect of life. 
Table 3: Children Involved with Criminal Cases in Accordance with their Relations with their Guardians (2014)

\begin{tabular}{clc}
\hline NO. & GUARDIANS & NO. OF CHILDREN \\
\hline 1. & Biological parents & 3371 \\
\hline 2. & Single mother & 680 \\
\hline 3. & Single father & 122 \\
\hline 4. & Mother and stepfather & 162 \\
\hline 5. & Father and stepmother & 65 \\
\hline 6. & Grandparents & 98 \\
\hline 7. & Relatives & 140 \\
\hline 8. & Living alone & 50 \\
\hline 9. & Living with friends & 89 \\
\hline 10. & Undefined/uncertain/breakaway & 19 \\
\hline 11. & Others $\quad$ Total & 357 \\
\hline & & 5153
\end{tabular}

Source: The Social Welfare Department of Malaysia 2014

Other than the divorce cases, the cases of domestic violence are also becoming more significant in number. In a report done by the Social Welfare Department of Malaysia, domestic violence cases happening in Malaysia prove to increase drastically in 2014. 696 cases involving female family members and 35 cases involving male members are reported that year, as compared to only 447 cases of female victims and 11 cases of male victims in the previous year. This increase by 35.98 percent in only a year is seen as a circumstantial evidence to the significance of marital education as an assurance for a peaceful household.

\section{Literature Review}

This particular study is going to analyse the effectiveness of Malaysian higher education system in providing students marital, parental and familial knowledge and skills as a preparation for them to manage their own families in the future. There were several studies and analysis done related to the issue we are addressing here, with one of them resulting in official requirement on taking the Pre-Marital Course that was introduced since 1990s to the couples who are getting married. It has been since conducted by the Division of Family, Society and Community under the Department of Islamic Development in Malaysia (JAKIM). Ruhil Hayati (2011) had done a research on this in her article titled Modul Kursus Praperkahwinan Islam: Kajian Terhadap Keberkesanannya di Jabatan Agama Islam Negeri Perak Darul Ridzuan (Muslim Pre-Marital Course Module: A Study on its Effectiveness in Islamic Department of Perak). Both studies were descriptive and inclusive of all aspects from the content to situational matters like program management and participants' views on the course.

A research on negotiation skills within a family was done by Rafida (2004) in her article called Negotiation Skills in Family Conflicts: Comparison between Rural and Urban Areas. Though it focuses more on the comparisons between families from rural and urban areas, the vital idea that it proposes is that negotiation skills, or communication in general, are necessary to form a harmonious family institution. Another similar research was also done by Azizi (2008) that 
deals with other aspects of familial essentiality which are decision-making and problemsolving skills.

Another topic that is related to this study that keeps attracting scholars to do researches on is divorce. One of the remarkable studies is an analysis done by Hamidah (2006) titled Faktor Penyumbang kepada Masalah Keluarga dan Penceraian: Kajian Kes di Johor (Factors Contributing to Family Issues and Divorce: Based on the Cases in Johore). This particular study as well as other studies give a clear evidence that lack of marital education is one of the reasons why the divorce rate keeps moving up.

\section{Research Objectives}

This research is meant to serve for these purposes:

1. To contemplate on the role of higher education system in providing marital education and awareness to the students.

2. To analyse the efforts done by selected public universities in inserting modules or topics related to marriage and family institution in the curriculum.

\section{Research Methodology}

In this particular research, qualitative method is used. Library research is needed to obtain clear-cut current information and statistics regarding the marital issues. Reference is also made based on documented sources and writings that have either direct or indirect links to the regarded matter. Policies, guidelines and circulars related to curriculum development within higher education institutions that were issued by the Department of Higher Education, Ministry of Education and Malaysian Qualifications Agency are thoroughly examined. Additionally, the handbook Garis Panduan Mata Pelajaran Pengajian Umum Edisi Kedua (Guidelines for General Studies Modules Second Edition) as well as academic curriculum guidelines in several public universities are being scrutinised too. This research is approvingly supported by leaders and scholars in the community.

\section{Finding and Research Dicussion}

National Higher Education is one of the significant social institutions of a nation as it acts as the major outlet for national development and sustainability (UTHM, 2012). Findings prove that higher education system in Malaysia makes a big platform to spread marital and familial awareness among youth. However, it is the institutions', or particularly universities' in this case, autonomous power to determine and organize the marriage-related modules according to the extent they think are needed. The following are some of the aspects that are analysed here:

\section{The Formation of National Education Philosophy}

The National Education Philosophy of Malaysia is:

"Education in Malaysia is an on-going effort towards further developing the potential of individuals in a holistic and integrated manner, so as to produce individuals who are intellectually, spiritually, emotionally and physically balanced and harmonious, based on a firm belief in and devotion to God. Such an effort is designed to produce Malaysian citizens who are knowledgeable and competent, who possess high moral standards, and who are responsible and capable of achieving high level of personal well-being as well as being able to contribute to the harmony and betterment of the family, the society and the nation at large". 
The function of education as "developing the potential of individuals in a holistic and integrated manner" as in the philosophy above should be expanded to potentials in marriage and family management. These potentials must be developed through formal education. Without the embracement of these family skills, the society as well as the nation as a whole would be in chaos.

Meanwhile, the education's purpose as to "produce Malaysian citizens who are knowledgeable and competent, who possess high moral standards, and who are responsible and capable of achieving high level of personal well-being" is very much similar to a marriage's. In fact, a marriage is considered as an opening place in the whole process of human edification. As Allah stated in al-Quran:

And of His signs is that He created for you from yourselves mates that you may find tranquillity in them; and He placed between you affection and mercy. Indeed in that are signs for people who give thought?

(Ar-Rum: 21)

The verse above clearly states that the bond of marriage that is made based on Islamic teachings will surely give the partners tranquillity as well as affection and mercy. These consequential qualities are the ones that produce individuals who are driven to contribute to the society and later, to the nation. Furthermore, one of the implicit purposes of marriage is to create outstanding and productive community members and citizens.

Therefore, it becomes every public national university's responsibility to ensure the curriculum they offer for every academic program include marital and familial education, aligned with the National Education Philosophy. This has to be paid full attention by all authoritative parties as it can be one of the effective efforts in countering the issue of the breakdown of family institution that keeps worsening nowadays.

\section{Implementation of General Studies Modules (MPU)}

General Studies Modules (MPU) is a set of mandatory modules required to be taken by Malaysian university students as one of the conditions for them to graduate (Jabatan Pengajian Tinggi, 2013). Reasons MPU is established are:

1. As a coordination for compulsory modules in national universities

2. Formation of Nation State

3. Mastery and Competency in Soft Skills

4. Mastery and Competency in Knowledge

5. Application of soft skills

Based on the reasons above, MPU is divided into four groups and students are required to pass and complete all the four groups to be able to graduate (Kementerian Pendidikan Tinggi, 2016). The structures of the groups are as Table 4 below. 
Table 4: Structures of MPU

\begin{tabular}{|c|c|c|}
\hline Group & $\begin{array}{c}\text { No. of Courses/Credit } \\
\text { Hours }\end{array}$ & Course Regulation \\
\hline $\begin{array}{l}\text { U1: } \begin{array}{l}\text { Comprehension of philosophies, } \\
\text { values and history }\end{array}\end{array}$ & $\begin{array}{c}2 \text { Courses } \\
\text { (4-6 credit hours) }\end{array}$ & $\begin{array}{l}\text { Regulated by Ministry } \\
\text { of Higher Education } \\
\text { (KPT) }\end{array}$ \\
\hline U2: Mastery in soft skills & $\begin{array}{c}1 \text { Course } \\
\text { (2-3 credit hours) }\end{array}$ & \multirow{3}{*}{$\begin{array}{l}\text { Regulated by the } \\
\text { Institutes of Higher } \\
\text { Education } \\
\text { according to suitability }\end{array}$} \\
\hline U3: Broad knowledge of Malaysia & $\begin{array}{c}1 \text { Course } \\
\text { (2-3 credit hours) }\end{array}$ & \\
\hline $\begin{array}{l}\text { U4: } \begin{array}{l}\text { Competency in management of } \\
\text { society, especially in terms of } \\
\text { practical works }\end{array}\end{array}$ & $\begin{array}{c}1 \text { Course } \\
\text { ( } 2 \text { credit hours) }\end{array}$ & \\
\hline
\end{tabular}

Source: Guidelines for General Studies Modules (MPU) Second Edition, 2016

The implementation of MPU clearly gives substantial contribution in developing citizens' personalities especially among the young. Via U2, which is the mastery in soft skills, courses relating to marriage and family can successfully be set in motion, and subsequently come to the aid of the government in mitigating the breakdown of family institution.

International Islamic University Malaysia (IIUM) is the only Malaysian public university that offers a module concerning purely on family and parenting skills as one of MPU modules. The subject matter is even clear on the module's name which is Family Management and Parenting (CCFM2052). The objectives of compelling the module to the students are:

1. Giving basic knowledge on marriage and parenting

2. Demonstrating parenting skills

3. Reviewing issues related to divorce and domestic violence

4. Discussing current social issues among students

\section{Options for Elective Modules}

The structure of academic programs in IPT is divided into three different categories which are university mandatory courses, program's core courses and elective courses. The division of credit hours' percentage for each category as set by the Council of National Higher Education (MPTN), except for the requirement of a professional body, is as Table 5 below.

Table 5: Division of Credit Hours' Percentage

\begin{tabular}{cc}
\hline Category & Percentage \\
\hline University mandatory courses & $15-20 \%$ \\
\hline Program's core courses & $50-60 \%$ \\
\hline Elective courses & $25-30 \%$ \\
\hline
\end{tabular}

Source: Guidelines for Application for Academic Programs Second Edition, KPT

Elective courses refer to course(s) that are optional and can be taken by students to complement their study programs or simply feed in their interests and potentials (UMT, 2005). These elective courses should include at least one module that particularly discusses 
marriage and family. Knowledge and understanding on the significance of strong family institution toward the nation's sustainability should as well be brought to the fore to the students.

Universiti Kebangsaan Malaysia (UKM), or The National University of Malaysia, has taken a proactive step in productizing elective courses according to current scenarios and demands. The handbook Garis Panduan Penyediaan dan Penawaran Kursus Citra (Kursus Baharu) or Guidelines for Preparation and Offer of Designated Courses (New Courses) (UKM, 2017) has been issued to guide faculties in the offer of elective courses. According to the guidelines, courses or modules that are intended to be established must comply with at least one of the six designations, as presented in Table 6 below.

Table 6: List of the Six Designations

\begin{tabular}{lll}
\hline Designation 1: & Ethics, Nationhood and Civilisation \\
\hline Designation 2: & $\begin{array}{l}\text { Languages, Communication and } \\
\text { Literacy }\end{array}$ & \\
\hline Designation 3: & $\begin{array}{l}\text { Qualitative } \\
\text { Reasoning }\end{array}$ & and Quantitative \\
\hline Designation 4: & $\begin{array}{l}\text { Leadership, Entrepreneurship and } \\
\text { Innovation }\end{array}$ \\
\hline Designation 5: & Science, Technology and Sustainability \\
\hline Designation 6: & Family, Health and Lifestyle \\
\hline ource: Circulars of the Designation Centre UKM No.1/2017
\end{tabular}

The formation of Designation 6 is very in line with current efforts in countering the phenomenon of the breakdown of family institution. Clear description of this particular designation is as follows (UKM Designation Centre, 2017):

The discussions about family consist of the definition of family and intergenerational relationships such as spouses, parents, children, siblings and neighbours. Early education in families shapes their personality, behaviour and healthy lifestyle. Good family dynamics means bringing satisfaction, happiness and success to the individuals and society. This domain provides knowledge, exposure and practical skills in a holistic manner to students about family, health and healthy lifestyle.

\section{Soft Skills Application}

Soft skills developed through academic programs in Malaysian higher institutions are meant to produce graduates who are skilful and competitive in the job sector (JPT, 2015), which subsequently will create first class human capital that will contribute to organisational progress and national development (UTHM, 2013). These skills include the generic skills below (UPM, 2006):

i. Communication skills

ii. Critical thinking and problem solving skills

iii. Teamwork

iv. Continuous learning and knowledge management

v. Morals and professional ethics

vi. Social responsibility 


\section{vii. Entrepreneurship \\ viii. Leadership}

Soft skills must not only be seen as students' preparation for their prospective work, but also for their personal corcerns ahead especially in matters related to marital and familial relationships. Leadership, management and problem solving are among the skills that are very much needed in the latter affairs. Within a marriage particularly, problems will always come arise, and the partners' capacity to manage the incoming conflicts depends on the level of the mentioned skills they possess (JAKIM, 2013), which makes all the seven skills very crucial to a marriage and also to a family as a whole. This is in accordance with a hadith by Muhammad (pbuh) that stresses the criteria of obedience to God and moral obligation as the major criteria a parent should consider to marry his daughter to. The hadith is translated as below:

"If there comes to you one whose religious commitment and attitude pleases you, then marry [your female relative who is under your care] to him."

Narrated by Tirmizi

\section{Conclusion}

Marital and familial education is seen as one of the essential education branches and should be highly accentuated to the young generation today. The scenario of the breakdown of family institution that keeps getting alarming and mostly involves young couples and young marriages must be dealt with as best as possible. All parties (governmental and nongovernmental) must act following their respective roles to counteract this unhealthy phenomenon.

Concerning this matter, Malaysian higher education system seems to play a huge role in the efforts countering this scenario by giving out formal education specially on marriage, family and parenting, in line with what is stated in the National Education Philosophy. Also, the formation of principles and guidelines by The Ministry of Higher Education Malaysia provides a big platform for marital and familial-related courses to be offered or made complusory to students. Malaysia's National (Higher) Education Blueprint, Quality Assurance Policy, Higher Education Department, Guidelines for General Studies Modules, Credit Distribution Policy by the Council of National Higher Education and Guidelines for Academic Program Writing are among supported documents that are made reference to on the involvement of marital and familial-related subjects in the structure of academic program in national higher education institutes.

Hence, in the researcher's view, these opportunities should be well utilised by national universities in their curriculum structures. This effort is important as it becomes a social responsibility of these universities to contribute significantly on the development and sustainability of the community. International Islamic University Malaysia (IIUM) and The National University of Malaysia (UKM) are among those that have proven to take proactive steps on this scenario. It is hoped that similar efforts can be done by other national universities to produce holistic young generation with high-minded personalities and contributive traits for the betterment of the family, the society and ultimately the country. 


\section{Acknowledgment}

This research is done with the sponsor of Special Research Grant Scheme (SRGS) - RR184. Highest appreciation is given to Universiti Sultan Zainal Abidin for the sponsor and support provided to make this research possible.

\section{Corresponding Author}

Nizaita Omar, Faculty of Islamic Contemporary Studies, Universiti Sultan Zainal Abidin (UniSZA), Gong Badak Campus, 21300 Kuala Nerus, Kuala Terengganu, Terengganu, Malaysia. Email: nizaitaomar@unisza.edu.my

\section{References}

Yahaya, A. (2008). Pembentukan Keluarga yang Bahagia: Cara Membuat Keputusan dan Cara Mengatasi Masalah Untuk Kecermelangan Keluarga chapter in book: Modal Insan: Keluarga Berkesan. Skudai: Penerbit UTM.

Ab. Rahman, H. (2006). Faktor Penyumbang kepada Masalah Keluarga dan Perceraian: Kajian Kes di Johor chapter in book: Institusi Keluarga Menghadapi Cabaran Alaf Baru. Kuala Lumpur: Utusan Publication \& Distribution Sdn. Bhd.

Jabatan Kebajikan Masyarakat (2014). Laporan Statistik Jabatan Kebajikan Masyarakat (JKM) 2014.

Jabatan Kemajuan Islam Malaysia. (2002) Garis Panduan Pengawalan Pelaksanaan Modul Kursus Bersepadu Kursus Praperkahwinan Islam. Putrajaya: JAKIM

Jabatan Kemajuan Islam Malaysia. (2013) Garis Panduan Pengawalan Pelaksanaan Modul Kursus Bersepadu Kursus Praperkahwinan Islam. Putrajaya: JAKIM

Daud, M. H. (2004). Pendidikan Keibubapaan: Satu Pengenalan Ringkas. Kertas Kerja dalam Seminar Antarabangsa Nilai dalam Komuniti Pasca Modenisme (SIVIC 2004), 4 -6 September 2004). Hotel City Bay view Langkawi

Pekeliling Jabatan Pengajian Tinggi Bil.2/2013: Penyelarasan Kursus Matapelajaran Wajib di

IPTS Ruj.: JPT? GS 1000-606 Jld 1 (25) bertarikh 27 Jun 2013

Pekeliling Pusat Citra Universiti Kebangsaan Malaysia Bil.1/2017: Garis panduan Penyediaan dan Penawaran Kursus Citra (Kursus Baharu) Ruj.: UKM/CTR/224/16 bertarikh 9 Januari 2017

Pelan Pembangunan Pendidikan Malaysia (Pendidikan Tinggi) 2015-2025, Kementerian Pendidikan Malaysia.

Rahim, R. N. A. (2004). Negotiation Skills in Family Conflicts: Comparison between Rural and Urban Areas. Selangor: Kolej Universiti Islam Malaysia. Retrieved from http://ddms.usim.edu.my

Hayati, R. (2011). Modul Kursus Praperkahwinan Islam: Kajian Terhadap Keberkesanannya Di Jabatan Agama Islam Negeri Perak Darul Ridzuan. Ijazah Sarjana yang tidak diterbitkan. Universiti Malaya 